LINGUAGEM MÉDICA

\title{
PROBABILIDADE EM MEDICINA
}

\section{Joffre M. de Rezende ${ }^{1}$}

A palavra probabilidade não é uma criação da matemática e muito menos da estatística.

O rastreamento do vocábulo nos conduz aos escritos de Cícero no século I a.C., que o empregou em latim (probabilitas, tatis) com o sentido de atributo ou caráter do que é verossímil, do que parece ser verdadeiro e suscetível de prova (1).

A evolução semântica da palavra conferiu-lhe a noção de incerteza que perdura nas línguas modernas.

A estatística nada mais fez do que incorporar o termo ao seu vocabulário, com acepção e definição próprias, dentro de um conceito matemático de quantificação de valores.

Este é um fenômeno comum a todas as línguas, denominado em Semântica de especialização do significado a um grupo social restrito e responsável pela polissemia das palavras (2). Para um advogado, por exemplo, a palavra ação significa naturalmente a ação judicial; para um cineasta, a obtenção de uma cena; para um militar, um combate; para um empresário, um título negociável na bolsa.

Isso me faz lembrar um artigo que li há tempos, escrito por um médico, justificando por que se generalizou o uso de "cirurgia" como sinônimo de "operação". Seria para não confundir com outros tipos de "operação", como operação financeira, bancária, etc. O Prof. Idel Becker comentou ironicamente: desse modo não vamos poder usar a palavra pé para não confundir com o pé de mesa, nem cabeça porque prego também tem cabeça.

Após essa digressão e voltando à "probabilidade em medicina", acredito que o importante é o contexto em que se emprega a expressão. Se ela é usada em sentido genérico, qualitativo, retratando uma situação ou um ponto de vista, como

1 Professor Emérito da Universidade Federal de Goiás.

Endereço para correspondência: E-mail: jmrezende@cultura.com.br http://usuarios.cultura.com.br/jmrezende

Recebido para publicação em: 13/2/2012. 
quando o médico opina sobre a provável sobrevida de um doente grave, neste caso faz parte da linguagem geral. Se é empregada com critério estatístico, como em uma pesquisa, passa a ter um significado específico, que se pode definir como um conceito matemático que permite a quantificação da incerteza e torna possível abordar, de forma racional, resultados imprevisíveis.

\section{REFERÊNCIAS}

1. Saraiva FR dos Santos. Dicionario latino-português, 10 ed. Rio de Janeiro: Liv. Garnier, 1993.

2. Ullmann S. Semântica. Uma introdução à ciência do significado. 4. ed. Lisboa: Fundação Calouste Gulbenkian, 1964. 